\title{
On the Hypocalciuric Action of Chlorothiazide
}

\author{
Linda S. Costanzo and I. M. Weiner \\ From the Department of Pharmacology, State University of New York, \\ Upstate Medical Center, Syracuse, New York 13210
}

\begin{abstract}
A B S T R A C T Clearance experiments were performed in female mongrel dogs, either intact or thyro-parathyroidectomized (T-PTX), under pentobarbital anesthesia, to examine the unusual hypocalciuric property of thiazide diuretics. The relationship between calcium clearance ( $\mathrm{C}_{\mathrm{Ca}}$ ) and sodium clearance $\left(\mathrm{C}_{\mathrm{Na}}\right)$ was determined in normal dogs, $\mathrm{C}_{\mathrm{Ca}}=0.79 \mathrm{C}_{\mathrm{Na}}$; constant infusion of chlorothiazide (CTZ) to provide drug concentrations in plasma of approximately $40 \mu \mathrm{g} / \mathrm{ml}$ modified this relationship; $\mathrm{C}_{\mathrm{Ca}}=0.30 \mathrm{C}_{\mathrm{Na}}(P<0.001)$. The magnitude of the dissociating effect of CTZ on the urinary $\mathrm{Ca} / \mathrm{Na}$ relationship was found to be most highly correlated with urinary drug concentration. Infusion of CTZ (1 mg/ $\mathrm{min}$ ) into one renal artery caused a unilateral decrease $(25 \%)$ in $\mathrm{C}_{\mathrm{ca}} / \mathrm{GFR}$ while producing a unilateral increase $(80 \%)$ in $\mathrm{C}_{\mathrm{Na}} / \mathrm{GFR}$. The same dose of $\mathrm{CTZ}$ in T-PTX dogs produced an increase in $\mathrm{C}_{\mathrm{Na}} / \mathrm{GFR}$ without causing a change in $\mathrm{C}_{\mathrm{C} a} / \mathrm{GFR}$. The defective response in T-PTX dogs could be ascribed to poor tubular secretion of the drug; when urinary drug concentrations were elevated in T-PTX dogs to the levels found in intact dogs (by infusing more drug), $\mathrm{C}_{\mathrm{Ca}} / \mathrm{GFR}$ fell to an equivalent extent. T-PTX dogs showed substantially lower renal extraction of $\mathrm{CTZ}(42 \%)$ than intact dogs $(57 \%)$; PTH administration to T-PTX dogs increased extraction toward normal $(49 \%)$. The defective secretion of $\mathrm{CTZ}$ could not be attributed to either a decreased tubular maximum or a decreased renal blood flow.
\end{abstract}

\section{INTRODUCTION}

Thiazide diuretics have two effects on calcium clearance not produced by most other natriuretic drugs. First,

This work was presented in part at the sixth Annual Meeting of the American Society of Nephrology, 1973. Part of this work was included in a dissertation submitted in partial fulfillment of the degree of Doctor of Philosophy by L. Costanzo.

Dr. Costanzo's present address is Department of Physiology, Cornell University Medical College, New York.

Received for publication 13 March 1974 and in revised form 10 May 1974. on initial administration they do not enhance calcium excretion in proportion to sodium excretion (1-14). This phenomenon is seen in most subjects, including those with hypoparathyroidism (11-13). Second, during sustained administration, thiazides cause a persistent reduction in calcium excretion $(4,5,11-13,15,16)$. The latter phenomenon has been observed in most subjects, but not those with hypoparathyroidism $(12,13)$.

Several hypotheses have been advanced to explain the effects of thiazides on calcium excretion and the impaired response in hypoparathyroid patients. Among the factors considered in these hypotheses are: the role of extracellular volume depletion $(16,17)$, direct stimulation of the parathyroid glands by the drugs (18), enhancement or potentiation of the renal calcium-retaining action of parathyroid hormone $(\mathrm{PTH})^{1}(12,13)$, and direct actions on the renal tubules (19). There is direct or probable evidence against some of these hypotheses (see below). Moreover, no one of the hypotheses advanced thus far can be itself explain all of the phenomena described above.

This paper summarizes the results of a study examining the acute hypocalciuric action of chlorothiazide (CTZ) in intact and thyro-parathyroidectomized (T-PTX) dogs. The results establish that the thiazides affect calcium excretion in large part by a direct action on the kidney. In these experiments, hypoparathyroidism modified this action of thiazides by influencing pharmacokinetics, not by making the kidney unresponsive to the drug. The results suggest that the dual action of thiazides (natriuretic and hypocalciuric) may be manifestations of a single effect. Finally, the results help explain why the acute administration of thiazides may cause variable effects on the magnitude of calcium clearance.

${ }^{1}$ Abbreviations used in this paper: $\mathrm{ADH}$, antidiuretic hormone; Art, concentration in arterial plasma; C, clearance; c-AMP, cyclic AMP; CTZ, chlorothiazide; GFR, glomerular filtration rate; $\mathrm{P}$, concentration in plasma; PTH, parathyroid hormone; $\mathrm{T}$, secretory rate; Tm, tubular maximum: T-PTX, thyro-parathyroidectomized; U, concentration in urine; V, urinary flow rate; Ven, concentration in renal venous plasma. 


\section{METHODS}

70 clearance experiments were performed in female mongrel dogs anesthetized with sodium pentobarbital, $30 \mathrm{mg} / \mathrm{kg}$, i.v. They were deprived of food but not water for $18 \mathrm{~h}$ before experiments. Enough inulin was infused to provide plasma concentrations of approximately $40 \mathrm{mg} / 100 \mathrm{ml}$. Blood samples were taken from the femoral artery at midpoints of clearance periods. Urine collections were usually made through ureteral cannulas placed near the bladder via a lower abdominal incision. Indwelling bladder catheters were used in those dogs subject to repeated experiments; bladders were washed out with $10 \mathrm{ml}$ of $5 \%$ mannitol before the start of a set of clearance periods and at the end of each clearance period. In experiments involving intra-arterial infusions, the left renal artery was exposed via a flank incision. A curved 23-gauge needle was inserted into the artery as close as possible to the aorta and proximal to any bifurcations. Dogs with multiple renal arteries were not used. The needles were kept patent by the infusion of $0.9 \%$ $\mathrm{NaCl}$ at $0.68-0.76 \mathrm{ml} / \mathrm{min}$. During appropriate clearance periods, drugs were added to the intra-arterial infusion. For collection of renal venous blood, the left renal vein was approached via a flank incision and a curved 23-gauge needle was placed in the renal vein between the kidney and the ovarian vein. The needle was kept in position (pointing toward the kidney) by applying tension in the appropriate direction. The needle and its connecting tubing was filled with heparinized saline when not in use.

Some experiments were performed in T-PTX dogs. These animals were subjected to the operation $48 \mathrm{~h}$ before experiments (20). On the day of operation, after recovery from anesthesia, the animals were given $25 \mathrm{~g}$ of calcium lactate mixed with canned $\operatorname{dog}$ food. On the subsequent day, the dose of calcium lactate was repeated and each animal received $30 \mathrm{mg}$ of dessicated thyroid orally.

Effect of $\mathrm{CTZ}$ on $\mathrm{Na}$-Ca relationship. Control experiments (five dogs, $15-29 \mathrm{~kg}$ ) began with the i.v. infusion of $0.9 \% \mathrm{NaCl}$ at $5 \mathrm{ml} / \mathrm{min}$ for $40 \mathrm{~min}$; at the end of this time a series of 1310 -min clearance periods were started. During these periods, urine flow was varied over a wide range by adding mannitol (5-15\%) to the infusion and by varying the rate $(5-8.6 \mathrm{ml} / \mathrm{min})$.

Similar experiments (four dogs, 15-25 kg) were performed in the presence of CTZ. A loading dose of CTZ (84 mg) was given at the same time that i.v. infusion was started. The initial saline infusion contained sufficient CTZ to deliver $5 \mathrm{mg} / \mathrm{min}$. The rate of $\mathrm{CTZ}$ infusion was increased to $6 \mathrm{mg} / \mathrm{min}$ near the end of the experiments to keep the drug concentration in plasma from falling as a consequence of volume expansion. The mean concentrations for CTZ in the various experiments ranged from 40-53 $\mu \mathrm{g} / \mathrm{ml}$. Within each experiment, the plasma concentration of CTZ remained fairly constant. In only 6 of the 52 clearance periods did the CTZ concentration deviate from the mean values of the various experiments by more than $10 \%$.

Dose-response experiments. In 10 experiments the dogs $(16-21 \mathrm{~kg})$ were loaded with $500 \mathrm{ml}$ of $5 \%$ mannitol in $0.9 \% \mathrm{NaCl}$ given at the rate of $21 \mathrm{ml} / \mathrm{min}$. An infusion of similar composition was continued at $8.6 \mathrm{ml} / \mathrm{min}$ for the remainder of the experiment. $40 \mathrm{~min}$ after completion of the loading infusion, two 10 -min control clearance periods were taken. CTZ was added to the infusions in amounts resulting in delivery of $1.5-7 \mathrm{mg} / \mathrm{min}$ in different dogs.
This procedure resulted in slowly rising concentrations of $\mathrm{CTZ}$ in plasma and urine over the ensuing six clearance periods.

Additional experiments of generally similar design were performed in three $\operatorname{dog}_{s}(17-20 \mathrm{~kg})$. In these experiments, urine flows were lower than in the preceding set because the initial load of mannitol-saline was either eliminated or decreased.

Renal arterial infusions of drugs. These experiments were patterned after those of Lavender and Pullman (21). The experimental protocol and weights of the dogs will be apparent from Tables I and II.

Tubular maximum $(T m)_{c r z}$ experiments. Four dogs $(17-20 \mathrm{~kg})$ were studied before and after thyro-parathyroidectomy. The dogs lost an average of $1.0 \mathrm{~kg}$ between the two experiments. An initial load of $20 \mathrm{mg}$ of CTZ and a sustaining infusion $(5 \mathrm{ml} / \mathrm{min})$ of $2 \%$ mannitol in $0.9 \% \mathrm{NaCl}$, containing $\mathrm{CTZ}$ to deliver $1.25 \mathrm{mg} / \mathrm{min}$, were given i.v. $40 \mathrm{~min}$ after beginning the experiments, two 10 min periods were taken. Three additional levels of CTZ in the plasma were achieved by administering loads of 60 $\mathrm{mg}, 320 \mathrm{mg}$, and $400 \mathrm{mg}$ of $\mathrm{CTZ}$ and increasing the CTZ in the infusions to deliver 5,25 , and $50 \mathrm{mg} / \mathrm{min}$, respectively. $20 \mathrm{~min}$ were allowed to elapse after the beginning of each new infusion; two 10-min clearance periods were then taken. The secretory rate $(\mathrm{T})_{\text {стz }}$ was calculated as the difference between $\mathrm{U}_{\text {ст }} \mathrm{V}$ and filtered $\mathrm{CTZ}$ [glomerular filtration rate $(G F R) \times C T Z$ concentration in an ultrafiltrate of plasma].

Renal blood flow experiments. 10 normal dogs (14-24 $\mathrm{kg})$ and 5 T-PTX dogs $(16-19 \mathrm{~kg})$ were used. Urine was collected separately from each kidney. A solution of $0.9 \%$ $\mathrm{NaCl}$ containing $\mathrm{CTZ}(5 \mathrm{mg} / \mathrm{min})$ was infused at $5 \mathrm{ml} /$ min throughout the experiment. After a 2-h equilibrium period, three 10 -min control periods were taken. At the midpoint of each period, arterial and renal venous blood were sampled simultaneously. After the control periods in T-PTX dogs, the animals were treated with either parathyroid extract (Eli Lilly \& Co., Indiananolis. Ind.) or a biologically active svnthetic fragment of PTH (Beckman Instruments, Inc., Fullerton, Calif.). $100 \mathrm{U}$ was given as a loading dose. and the hormone was added to the infusion to deliver $3 \mathrm{U} / \mathrm{min}$. $5 \mathrm{~min}$ after the loading dose of hormone, a series of three 10 -min collections was started. Since the results with the extract and the synthetic frasment were essentially the same. the data were pooled. Renal Dlasma flow was calculated on the basis of the CT7 determinations according to the Wolf equation (22) and converted to blood flow on the basis of hematocrit.

Analytical methods. Inulin (23), phosphate (24), calcium (25), and CTZ (26) were determined according to nuhlished methods. Urinary cvclic AMP was measured by radinimmunoassay with the Schwarz/Mann (Div.. Becton, Dickinson \& Co., Orangeburg, N. Y.) kit. Sodium was determined by flame photometry. Ultrafiltrates of nlasma ware prenared anaerobically in an atmosphere of $95 \% \mathrm{O}_{2}-5 \% \mathrm{CO}_{2}$ at $37^{\circ} \mathrm{C}$ according to Toribara, Terepka. and Dewey (27). Student's $t$ test was used for statistical comnarisnns. Paired comparisons were made where appropriate. Data are presented as means \pm SEM. Where necessary, linear regressions were calculated by the method of least squares.

Clearances and clearance ratios in the figures and tables are calculated in terms of total plasma calcium. Sufficient data are provided for the reader to convert these to fractional excretion if desired.

The Hypocalciuric Action of Chlorothiazide 629 


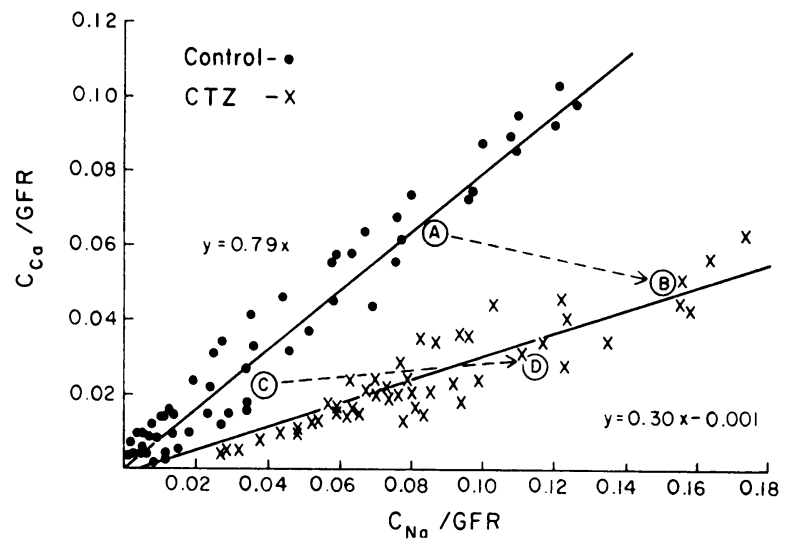

Figure 1 Relationship between $\mathrm{C}_{\mathrm{Ca}_{\mathrm{a}}} / \mathrm{GFR}$ and $\mathrm{C}_{\mathrm{Na}} / \mathrm{GFR}$ in control and CTZ-treated dogs. For control dogs, $r=0.96$; for CTZ-treated dogs, $r=0.81$. Points A, B, C, and D are data from other experiments and will be explained in the discussion.

\section{RESULTS}

Effect of CTZ infusion on the relationship between calcium and sodium clcarance ratios in intact dogs. Fig. 1 confirms the linear relationship between the clearance ratios of calcium and sodium in normal dogs (28). Also shown are the results from dogs receiving intravenous CTZ. Under the influence of the drug, the clearance ratios for calcium and sodium remained linearly related but at any level of sodium excretion, calcium reabsorption was enhanced, compared to controls. The slopes of the regression lines are significantly different: $P<$ 0.001 ; the intercept (Fig. 1) is not significantly different from zero. Mean values for GFR, concentration in plasma $(\mathrm{P})_{\mathrm{Ca}}$ and percent of $\mathrm{P}_{\mathrm{Ca}}$ ultrafilterable in the control and experimental groups were not significantly different; they were $56.9 \pm 3.4$ and $53.1 \pm 3.0 \mathrm{ml} / \mathrm{min} ; 2.51 \pm 0.03$ and $2.65 \pm 0.04 \mathrm{mM}$; and $68.3 \pm 1.9$ and $67.2 \pm 1.3 \%$, respectively. Not given in the figure are the equations based on the clearance ratio for ultrafilterable calcium. They are $y=1.17 x+0.008$ and $y=0.46 x-0.003$ for control and CTZ groups, respectively; the slopes are significantly different $(P<0.001)$.

Dose-response rclationship. A series of 10 clearance experiments was performed in dogs undergoing osmotic diuresis in which the effects of increasing levels of CTZ were monitored. The fall in the ratio $\mathrm{C}_{\mathrm{Ca}} / \mathrm{C}_{\mathrm{Na}}$ (expressed as a percent of the predrug ratio), is plotted as a function of $\mathrm{P}_{\mathrm{crz}}, \mathrm{U}_{\mathrm{crz}} \mathrm{V}$, and $\mathrm{U}_{\text {стz }}$ in Fig. 2, closed symbols. In each of the scattergrams there seems to be a positive correlation between the drug parameter and the magnitude of effect. Also included in this figure are 18 data points from three dogs in which there was minimal background osmotic diuresis, i.e. urine flows were generally lower than in the other ten experiments. These experi- ments yielded data that do not conform to the others in two of the scattergrams, but fit reasonably well in the mass plot with $\mathrm{U}_{\text {crz }}$ on the abscissa. There are already results in the literature that suggest that the natriuretic (29) and hypocalciuric (30) actions of thiazides are related to some parameter of drug excretion. The present data suggest that the hypocalciuric response is re-

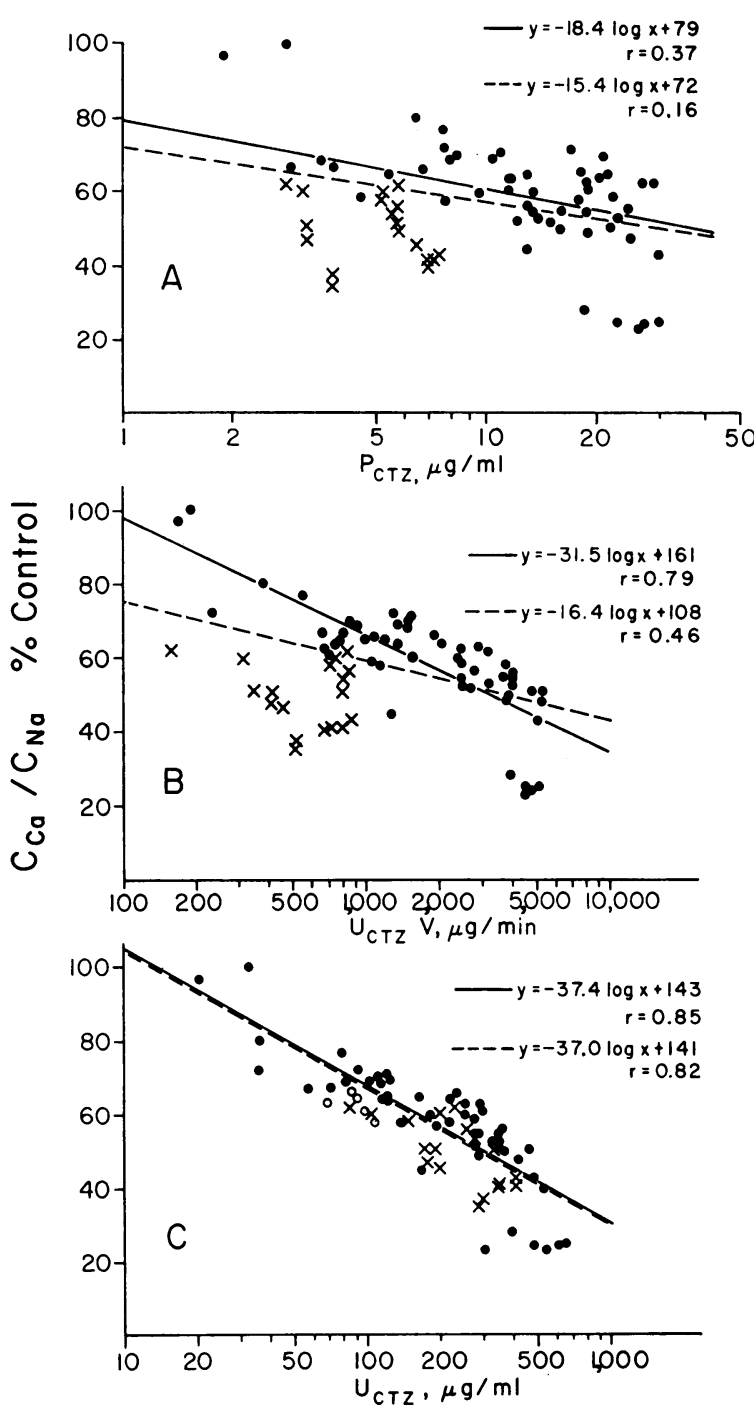

Figure 2 Response to $\mathrm{CTZ}$ of $\mathrm{C}_{\mathrm{C}_{\mathrm{a}}} / \mathrm{C}_{\mathrm{Na}}$, expressed as percent of control value for each dog, as a function of $\mathrm{P}_{\mathrm{CTZ}}$ (A), $\mathrm{U}_{\mathrm{crz}} \mathrm{V}$ (B), and $\mathrm{U}_{\mathrm{CTZ}}(\mathrm{C})$. Closed circles are data from $10 \mathrm{dogs}$ in which urinary flow rates were high; $\mathrm{x}$ 's are data from 3 dogs in which urinary flow rates were substantially lower. The solid regression lines were determined with only the high-flow data; the broken lines were determined from all the data. A, The slopes of the two lines are not significantly different from one another; B, The slope of the solid line is significantly greater than the slope of the broken line, $P<0.005 ; \mathrm{C}$, The slopes of the two lines are not significantly different from one another. 
lated to drug concentration in urine (tubular fluid) rather than total quantity of drug in urine.

In the experiments described in the preceding section, we encountered urinary concentrations of $\mathrm{CTZ}$ from 400 to $3,000 \mu \mathrm{g} / \mathrm{ml}$. Over this range of concentrations, there was no consistent change in $\mathrm{Cca}_{\mathrm{Ca}} / \mathrm{C}_{\mathrm{xa}}$. Consequently, we assume that the lower line in Fig. 1 describes the maximal or near-maximal effect of $\mathrm{CTZ}$.

Renal arterial infusions of CTZ or furosemide. Table I gives the details of an experiment in which CTZ, 1 $\mathrm{mg} / \mathrm{min}$, was infused into one renal artery of a normal dog. During the control periods renal function was approximately the same in both kidneys. During the infusion of $\mathrm{CTZ}$ into the left renal artery, there was essentially no change in GFR, but there was a considerable increase in $\mathrm{C}_{\mathrm{Na}} / \mathrm{GFR}$ on the left side, a smaller increase on the right, a $25 \%$ decline of $\mathrm{C}_{\mathrm{Ca}} / \mathrm{GFR}$ on the left side, and no change on the right. As a consequence of these changes, the ratio $\mathrm{C}_{\mathrm{Ca}} / \mathrm{C}_{\mathrm{xa}}$ fell from 0.66 to 0.23 on the infused side and less on the control side. There seemed to be a small unilateral effect on $\mathrm{C}_{\mathrm{PO}_{4}} / \mathrm{GFR}$ in this experiment, but this was not a consistent finding. This experiment and four others are summarized in Table II (group 2). The grouped data are consistent with the foregoing description of the single experiment.

Cyclic AMP (c-AMP) excretion was evaluated in this same group of dogs. Before drug infusions, c-AMP excretion was $505 \pm 99$ and $477 \pm 36 \mathrm{pmol} / \mathrm{min}$ from the experimental and control kidneys, respectively. During drug infusion, c-AMP excretion was lower from both kidneys; the changes were $-117 \pm 111$ and $-76 \pm 62$ $\mathrm{pmol} / \mathrm{min}$ from the experimental and control kidneys, respectively. These changes were not statistically sig- nificant. In view of the negative results, determinations of c-AMP excretion were omitted from the studies described subsequently.

The foregoing results on electrolyte clearances are to be compared with those from similar experiments with furosemide (Table II, group 1). The latter drug, infused at $15 \mu \mathrm{g} / \mathrm{min}$, also produced a largely unilateral natriuresis of similar magnitude. However, the clearances of calcium increased in proportion to the clearances of sodium and there was no significant change in $\mathrm{C}_{\mathrm{ca}} / \mathrm{C}_{\mathrm{Na}}$ attributable to the drug. This difference between the actions of chlorothiazide and furosemide is already well established $(12,14)$; the results with furosemide are included to validate our experimental procedure.

The experiments with $1 \mathrm{mg} / \mathrm{min} \mathrm{CTZ}$ into the left renal artery, were repeated in T-PTX dogs (Table II, group 4). The natriuresis on the left side was less than in normal dogs, but the difference between the two groups was not statistically significant. In T-PTX dogs, $\mathrm{CTZ}$ produced no important changes in $\mathrm{C}_{\mathrm{ca}} / \mathrm{GFR}$, although the increment in $\mathrm{Cxa}_{\mathrm{a}}$ was sufficient to result in a significant fall in the ratio of $\mathrm{C}_{\mathrm{Ca}} / \mathrm{C}_{\mathrm{Na}}$. Thus the T-PTX dogs seemed to have a blunted response to CTZ. The drug seemed to prevent increments in $\mathrm{C}_{\mathrm{ca}} / \mathrm{GFR}$ but it did not cause an absolute decline in $\mathrm{C}_{\mathrm{ca}} / \mathrm{GFR}$. Most of the subsequent experiments were attempts to explain this apparently blunted response to CTZ in T-PTX dogs.

To confirm the proper placement of needles for renal artery infusions, we routinely assayed the urinary excretion of $\mathrm{CTZ}$, expecting and finding excretion predominantly from the infused kidney. There was, however, a quantitative difference between normal and T-PTX dogs. Normal dogs excreted $1.027 \pm 0.042 \mathrm{mg} /$

TABLE I

Effect of $\mathrm{CTZ}$ on $\mathrm{Na}, \mathrm{Ca}$, and $\mathrm{PO}_{4}$ Clearances in a Normal Dog $(21 \mathrm{~kg})$

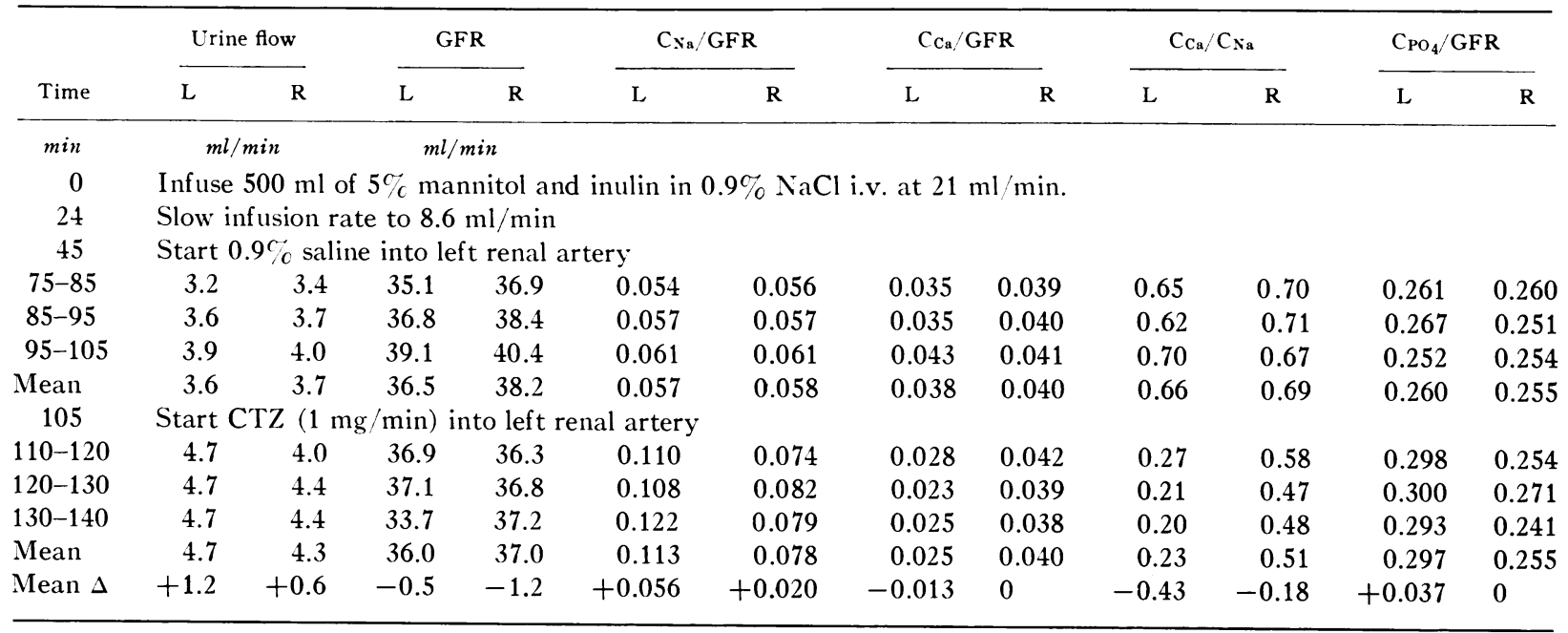

L, left kidney; R, right kidney. Mean $\Delta$ is the difference between the means of the parameters after CTZ infusion. 
TABLE II

Summary of Experiments Using Renal Arterial Infusion of Furosemide or Chlorothiazide in Intact and T-PTX Dogs

\begin{tabular}{|c|c|c|c|c|c|c|c|c|c|c|c|c|}
\hline \multirow{2}{*}{$\begin{array}{c}\text { Group } \\
\text { mean } \\
\text { body } \\
\text { weight, } \\
\text { (range) }\end{array}$} & \multirow{2}{*}{$\begin{array}{c}\text { Condition, } \\
\text { drug, } \\
\text { (infusion rate) }\end{array}$} & & \multicolumn{2}{|c|}{ GFR } & \multicolumn{2}{|c|}{$\mathrm{C}_{\mathrm{Na}} / \mathrm{GFR}$} & \multicolumn{2}{|c|}{$\mathrm{C}_{\mathrm{Ca}} / \mathrm{GFR}$} & \multicolumn{2}{|c|}{$\mathrm{C} \mathrm{Ca} / \mathrm{C}_{\mathrm{Na}}$} & \multicolumn{2}{|c|}{$\mathrm{CPO}_{4} / \mathrm{GFR}$} \\
\hline & & & $\mathrm{L}$ & $\mathbf{R}$ & $\mathrm{L}$ & $\mathbf{R}$ & $\mathrm{L}$ & $\mathbf{R}$ & $\mathbf{L}$ & $\mathbf{R}$ & L & $\mathbf{R}$ \\
\hline$k g$ & \multicolumn{12}{|c|}{$m l / m i n$} \\
\hline 1 & Intact & $\mathrm{C}$ & $\begin{array}{r}40.4 \\
\pm 2.9\end{array}$ & $\begin{array}{r}41.3 \\
\pm 3.8\end{array}$ & $\begin{array}{r}0.073 \\
\pm 0.014\end{array}$ & $\begin{array}{r}0.068 \\
\pm 0.012\end{array}$ & $\begin{array}{r}0.053 \\
\pm 0.008\end{array}$ & $\begin{array}{r}0.051 \\
\pm 0.007\end{array}$ & $\begin{array}{r}0.76 \\
\pm 0.05\end{array}$ & $\begin{array}{r}0.78 \\
\pm 0.04\end{array}$ & $\begin{array}{r}0.256 \\
\pm 0.017\end{array}$ & $\begin{array}{r}0.267 \\
\pm 0.035\end{array}$ \\
\hline 17.6 & Furosemide & $\mathrm{E}$ & 39.6 & 41.2 & 0.138 & 0.077 & 0.104 & 0.057 & 0.77 & 0.77 & 0.209 & 0.226 \\
\hline$(18-2.3)$ & $(15 \mu \mathrm{g} / \mathrm{min})$ & $\Delta$ & $\begin{array}{l} \pm 3.4 \\
-0.8 \\
\pm 0.7\end{array}$ & $\begin{array}{l} \pm 4.1 \\
-0.1 \\
\pm 0.2\end{array}$ & $\begin{array}{l} \pm 0.024 \\
+0.065 \\
\pm 0.0118\end{array}$ & $\begin{array}{l} \pm 0.014 \\
+0.009 \\
\pm 0.002 *\end{array}$ & $\begin{array}{l} \pm 0.016 \\
+0.051 \\
\pm 0.0108\end{array}$ & $\begin{array}{l} \pm 0.008 \\
+0.006 \\
\pm 0.002\end{array}$ & $\begin{array}{l} \pm 0.05 \\
+0.01 \\
\pm 0.03\end{array}$ & $\begin{array}{l} \pm 0.05 \\
-0.01 \\
\pm 0.02\end{array}$ & $\begin{array}{l} \pm 0.035 \\
-0.047 \\
\pm 0.019\end{array}$ & $\begin{array}{l} \pm 0.025 \\
-0.040 \\
\pm 0.021\end{array}$ \\
\hline 2 & Intact & $\mathrm{C}$ & $\begin{array}{r}40.9 \\
\pm 4.3\end{array}$ & $\begin{array}{r}41.3 \\
\pm 3.6\end{array}$ & $\begin{array}{r}0.085 \\
\pm 0.010\end{array}$ & $\begin{array}{r}0.087 \\
\pm 0.013\end{array}$ & $\begin{array}{r}0.064 \\
\pm 0.012\end{array}$ & $\begin{array}{r}0.066 \\
\pm 0.011\end{array}$ & $\begin{array}{r}0.81 \\
\pm 0.05\end{array}$ & $\begin{array}{r}0.81 \\
\pm 0.04\end{array}$ & $\begin{array}{r}0.344 \\
\pm 0.061\end{array}$ & $\begin{array}{r}0.343 \\
\pm 0.062\end{array}$ \\
\hline 21.3 & CTZ & $\mathrm{E}$ & $\begin{array}{r}38.8 \\
\pm 3.7\end{array}$ & $\begin{array}{r}38.6 \\
\pm 3.0\end{array}$ & $\begin{array}{r}0.153 \\
\pm 0.019\end{array}$ & $\begin{array}{r}0.108 \\
\pm 0.010\end{array}$ & $\begin{array}{r}0.048 \\
\pm 0.009\end{array}$ & $\begin{array}{r}0.063 \\
\pm 0.011\end{array}$ & $\begin{array}{r}0.39 \\
\pm 0.07\end{array}$ & $\begin{array}{r}0.63 \\
\pm 0.05\end{array}$ & $\begin{array}{r}0.302 \\
\pm 0.045\end{array}$ & $\begin{array}{r}0.270 \\
\pm 0.087\end{array}$ \\
\hline$(19-23)$ & $(1 \mathrm{mg} / \mathrm{min})$ & $\Delta$ & $\begin{array}{l}-2.1 \\
\pm 0.8\end{array}$ & $\begin{array}{l}-2.7 \\
\pm 0.7\end{array}$ & $\begin{array}{l}+0.068 \\
\pm 0.019 *\end{array}$ & $\begin{array}{l}+0.021 \\
\pm 0.008\end{array}$ & $\begin{array}{l}-0.016 \\
\pm 0.003 \S\end{array}$ & $\begin{array}{l}-0.003 \\
\pm 0.003\end{array}$ & $\begin{array}{l}-0.42 \\
\pm 0.04 \S\end{array}$ & $\begin{array}{l}-0.22 \\
\pm 0.06^{*}\end{array}$ & $\begin{array}{l}-0.042 \\
\pm 0.026\end{array}$ & $\begin{array}{l}-0.072 \\
\pm 0.030\end{array}$ \\
\hline 3 & Intact & $\mathrm{C}$ & $\begin{array}{r}38.9 \\
\pm 8.6\end{array}$ & $\begin{array}{r}39.1 \\
\pm 8.1\end{array}$ & $\begin{array}{r}0.088 \\
\pm 0.027\end{array}$ & $\begin{array}{r}0.093 \\
\pm 0.034\end{array}$ & $\begin{array}{r}0.089 \\
\pm 0.037\end{array}$ & $\begin{array}{r}0.090 \\
\pm 0.042\end{array}$ & $\begin{array}{r}0.90 \\
\pm 0.07\end{array}$ & $\begin{array}{r}0.92 \\
\pm 0.09\end{array}$ & $\begin{array}{r}0.277 \\
\pm 0.020\end{array}$ & $\begin{array}{r}0.280 \\
\pm 0.015\end{array}$ \\
\hline 23.1 & CTZ & $\mathrm{E}$ & $\begin{array}{r}40.6 \\
\pm 8.8\end{array}$ & $\begin{array}{r}40.7 \\
\pm 8.9\end{array}$ & $\begin{array}{r}0.116 \\
\pm 0.030\end{array}$ & $\begin{array}{r}0.109 \\
\pm 0.035\end{array}$ & $\begin{array}{r}0.090 \\
\pm 0.035\end{array}$ & $\begin{array}{r}0.091 \\
\pm 0.040\end{array}$ & $\begin{array}{r}0.70 \\
\pm 0.06\end{array}$ & $\begin{array}{r}0.73 \\
\pm 0.05\end{array}$ & $\begin{array}{r}0.276 \\
\pm 0.020\end{array}$ & $\begin{array}{r}0.276 \\
\pm 0.018\end{array}$ \\
\hline$(18-27)$ & $(0.75 \mathrm{mg} / \mathrm{min})$ & $\Delta$ & $\begin{array}{l}+1.7 \\
\pm 0.9\end{array}$ & $\begin{array}{l}+1.6 \\
\pm 1.1\end{array}$ & $\begin{array}{l}+0.028 \\
\pm 0.006^{*}\end{array}$ & $\begin{array}{l}+0.016 \\
\pm 0.007\end{array}$ & $\begin{array}{l}+0.001 \\
\pm 0.003\end{array}$ & $\begin{array}{l}+0.001 \\
\pm 0.004\end{array}$ & $\begin{array}{l}-0.20 \\
\pm 0.04^{*}\end{array}$ & $\begin{array}{l}-0.19 \\
\pm 0.04^{*}\end{array}$ & $\begin{array}{l}-0.001 \\
\pm 0.009\end{array}$ & $\begin{array}{l}-0.004 \\
\pm 0.010\end{array}$ \\
\hline 4 & T-PTX & $\mathrm{C}$ & $\begin{array}{r}43.5 \\
\pm 3.5\end{array}$ & $\begin{array}{r}43.5 \\
\pm 4.2\end{array}$ & $\begin{array}{r}0.063 \\
\pm 0.010\end{array}$ & $\begin{array}{r}0.065 \\
\pm 0.012\end{array}$ & $\begin{array}{r}0.058 \\
\pm 0.007\end{array}$ & $\begin{array}{r}0.059 \\
\pm 0.006\end{array}$ & $\begin{array}{r}0.96 \\
\pm 0.08\end{array}$ & $\begin{array}{r}0.99 \\
\pm 0.09\end{array}$ & $\begin{array}{r}0.110 \\
\pm 0.029\end{array}$ & $\begin{array}{r}0.107 \\
\pm 0.033\end{array}$ \\
\hline 19.2 & CTZ & $\mathrm{E}$ & $\begin{array}{r}40.7 \\
\pm 3.2\end{array}$ & $\begin{array}{r}40.5 \\
\pm 3.5\end{array}$ & $\begin{array}{r}0.102 \\
\pm 0.011\end{array}$ & $\begin{array}{r}0.089 \\
\pm 0.011\end{array}$ & $\begin{array}{r}0.054 \\
\pm 0.007\end{array}$ & $\begin{array}{r}0.060 \\
\pm 0.007\end{array}$ & $\begin{array}{r}0.56 \\
\pm 0.05\end{array}$ & $\begin{array}{r}0.70 \\
\pm 0.08\end{array}$ & $\begin{array}{r}0.102 \\
\pm 0.027\end{array}$ & $\begin{array}{r}0.110 \\
\pm 0.034\end{array}$ \\
\hline$(16-21)$ & $(1 \mathrm{mg} / \mathrm{min})$ & $\Delta$ & $\begin{array}{l}-2.8 \\
\pm 1.9\end{array}$ & $\begin{array}{l}-3.0 \\
\pm 2.1\end{array}$ & $\begin{array}{l}+0.039 \\
\pm 0.004 \ddagger\end{array}$ & $\begin{array}{l}+0.023 \\
\pm 0.002 \ddagger\end{array}$ & $\begin{array}{l}-0.004 \\
\pm 0.004\end{array}$ & $\begin{array}{l}+0.001 \\
\pm 0.004\end{array}$ & $\begin{array}{l}-0.40 \\
\pm 0.04 \S\end{array}$ & $\begin{array}{l}-0.29 \\
\pm 0.05_{+}^{+}\end{array}$ & $\begin{array}{l}-0.008 \\
\pm 0.015\end{array}$ & $\begin{array}{l}+0.003 \\
\pm 0.020\end{array}$ \\
\hline 5 & T-PTX & $\mathrm{C}$ & $\begin{array}{r}43.0 \\
\pm 3.1\end{array}$ & $\begin{array}{r}43.5 \\
\pm 3.3\end{array}$ & $\begin{array}{r}0.078 \\
\pm 0.008\end{array}$ & $\begin{array}{r}0.059 \\
+0.008\end{array}$ & $\begin{array}{r}0.074 \\
\pm 0.006\end{array}$ & $\begin{array}{r}0.052 \\
\pm 0.006\end{array}$ & $\begin{array}{r}0.97 \\
\pm 0.05\end{array}$ & $\begin{array}{r}0.90 \\
\pm 0.06\end{array}$ & $\begin{array}{r}0.102 \\
\pm 0.026\end{array}$ & $\begin{array}{r}0.099 \\
\pm 0.024\end{array}$ \\
\hline 22.8 & CTZ & $\mathrm{E}$ & $\begin{array}{r}42.4 \\
\pm 3.3\end{array}$ & $\begin{array}{r}41.5 \\
\pm 3.0\end{array}$ & $\begin{array}{r}0.126 \\
\pm 0.012\end{array}$ & $\begin{array}{r}0.084 \\
\pm 0.012\end{array}$ & $\begin{array}{r}0.046 \\
\pm 0.008\end{array}$ & $\begin{array}{r}0.043 \\
\pm 0.008\end{array}$ & $\begin{array}{r}0.36 \\
\pm 0.04\end{array}$ & $\begin{array}{r}0.52 \\
\pm 0.07\end{array}$ & $\begin{array}{r}0.108 \\
\pm 0.031\end{array}$ & $\begin{array}{r}0.085 \\
\pm 0.024\end{array}$ \\
\hline$(19-26)$ & $(1.5 \mathrm{mg} / \mathrm{min})$ & $\Delta$ & $\begin{array}{l}-0.6 \\
\pm 1.1\end{array}$ & $\begin{array}{l}-2.0 \\
\pm 0.6\end{array}$ & $\begin{array}{l}+0.048 \\
\pm 0.006 \S\end{array}$ & $\begin{array}{l}+0.025 \\
\pm 0.005\end{array}$ & $\begin{array}{l}-0.028 \\
\pm 0.005 \S\end{array}$ & $\begin{array}{l}-0.009 \\
\pm 0.003\end{array}$ & $\begin{array}{l}-0.61 \\
\pm 0.06 \S\end{array}$ & $\begin{array}{l}-0.38 \\
\pm 0.05 \S\end{array}$ & $\begin{array}{l}+0.006 \\
\pm 0.006\end{array}$ & $\begin{array}{l}-0.014 \\
\pm 0.006\end{array}$ \\
\hline
\end{tabular}

For each experiment, the means from three control and three experimental periods were used to calculate the group means and standard errors. $n=5$ throughout the table. $\Delta$ is the mean of differences between control and experimental observations. The significance of these differences is indicated by the following symbols: $* P<0.05 ; \ddagger P<0.02 ; \S P<0.01$. Other abbreviations are as in Table I and footnote 1 . There were five dogs in each group.

min of $\mathrm{CTZ}$ on the infused side (essentially $100 \%$ of infusion), while T-PTX dogs excreted only $0.723 \pm$ $0.093 \mathrm{mg} / \mathrm{min}$ via the corresponding kidney $(P<0.05){ }^{2}$ To test the possibility that this difference in CTZ excretion was responsible for the different results in the two groups of animals, we performed two additional series of experiments.

In the first series, CTZ was infused into the left renal arteries of normal dogs at $0.75 \mathrm{mg} / \mathrm{min}$ to attain the unilateral excretion rate encountered previously in T-PTX dogs (Table II, group 3 ). This procedure resulted in a mean unilateral excretion rate of $0.725 \pm$ $0.016 \mathrm{mg} / \mathrm{min}$ and a pattern of electrolyte clearances similar to that seen with the T-PTX dogs receiving drug at $1 \mathrm{mg} / \mathrm{min}$. That is, $\mathrm{C}_{\mathrm{Ca}} / \mathrm{GFR}$ did not change in

\footnotetext{
${ }^{2}$ The defect in drug excretion on the infused side in $\mathrm{T}$ PTX dogs was reflected in an enhanced excretion of CTZ on the contralateral side, as compared to normal dogs ( 80 \pm 18 vs. $41 \pm 8 \mu \mathrm{g} / \mathrm{min})$.
}

association with the enhanced $\mathrm{C}_{\mathrm{Na}} / \mathrm{GFR}$, but the ratio $\mathrm{C}_{\mathrm{Ca}} / \mathrm{C}_{\mathrm{Na}}$ fell.

In the next series of experiments, CTZ was infused into the left renal arteries of T-PTX dogs at $1.5 \mathrm{mg} / \mathrm{min}$ in an attempt to increase unilateral drug excretion to the level seen in normal dogs of group 2. This procedure resulted in excretion rates of $1.23 \pm 0.043 \mathrm{mg} / \mathrm{min}$, somewhat higher than the rates desired. These animals ( Table II, group 5) responded like normal dogs receiving intra-arterial infusions of $1 \mathrm{mg} / \mathrm{min}$, i.e., there was a fall in the ratio, $\mathrm{C}_{\mathrm{Ca}} / \mathrm{C}_{\mathrm{Na}}$ and an absolute fall in $\mathrm{C}_{\mathrm{Ca}} / \mathrm{GFR}$ of $38 \%$. The relationships between fractional fall in $\mathrm{C}_{\mathrm{Ca}} /$ GFR and CTZ excretion or concentration in urine are shown in Fig. 3.

The mean value for $\mathrm{C}_{\mathrm{Ca}} / \mathrm{C}_{\mathrm{Na}}$ in T-PTX dogs $(n=10)$ was $0.96 \pm 0.04$, significantly higher than the mean ratio, $0.82 \pm 0.04$, in intact dogs $(n=15), P<0.01$.

The values for plasma electrolytes in the five groups of dogs are listed in Table III. In no case did the drug 

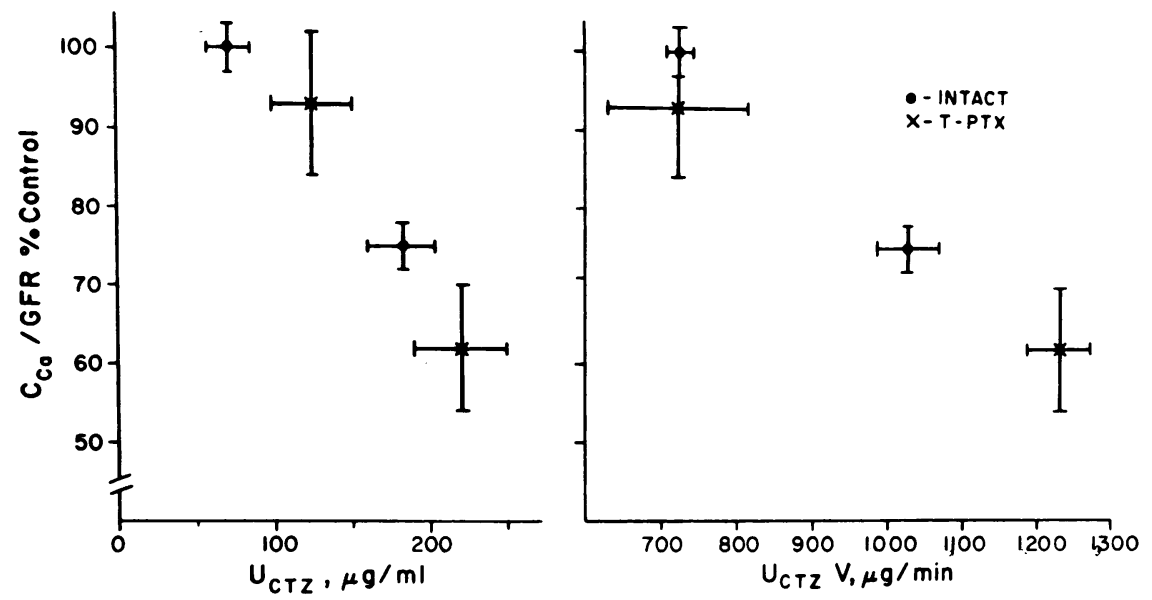

FIGURE 3 Fractional decline in $\mathrm{C}_{\mathrm{Ca}} / \mathrm{GFR}$ in intact and T-PTX dogs as a function of $\mathrm{U}_{\mathrm{CTZ}}$ (left) and $\mathrm{U}_{\text {стz }} \mathrm{V}$ (right). Data are means \pm SEM of results from five dogs.

infusions result in a significant change in any of the parameters measured. There were significant differences between intact and T-PTX dogs in $\mathrm{Pca}_{\mathrm{ca}}$ and percent of $\mathrm{Ca}$ ultrafilterable. The means of pooled data for plasma calcium were $2.76 \pm 0.05 \mathrm{mM}$ for intact dogs and $2.07 \pm$ $0.06 \mathrm{mM}$ for T-PTX dogs, $P<0.001$. The means for percent of $\mathrm{Ca}$ ultrafilterable were $72.9 \pm 0.9 \%$ for intact dogs and $60.2 \pm 1.2 \%$ for T-PTX dogs, $P<0.001$. The values for $\mathrm{P}_{\mathrm{PO}_{4}}, 1.39 \pm 0.07 \mathrm{mM}$ (intact) and $1.53 \pm$ $0.12 \mathrm{mM}$ (T-PTX), were not significantly different.
Tmcrz. The Tm for chlorothiazide was determined in four normal dogs. 8 days later a thyro-parathyroidectonly was performed and the Tm experiments were repeated $48 \mathrm{~h}$ after surgery. Fig. 4 displays the results from one dog according to Shannon's convention (31). The dog weighed $17.0 \mathrm{~kg}$ before and $16.0 \mathrm{~kg}$ after T-PTX. There was no significant difference in T/GFR at the two highest plasma concentrations in each experiment, and thus it is assumed that the mean of these values gives the $\mathrm{Tm} / \mathrm{GFR}$. In the control experiment the mean value

TABLE III

Summary of Plasma Electrolytes in Experiments Using Renal Arterial Infusion of Drugs

\begin{tabular}{|c|c|c|c|c|c|}
\hline $\begin{array}{c}\text { Condition, } \\
\text { drug, } \\
\text { (infusion rate) }\end{array}$ & & $\mathrm{P}_{\mathrm{Na}}$ & $\mathrm{P}_{\mathrm{Ca}}$ & $\begin{array}{c}\text { Ca } \\
\text { ultrafilterable }\end{array}$ & $\mathrm{PPO}_{4}$ \\
\hline & & $m M$ & $m M$ & $\%$ & $m . M$ \\
\hline $\begin{array}{l}\text { Intact } \\
\text { Furosemide } \\
(15 \mu \mathrm{g} / \mathrm{min})\end{array}$ & $\begin{array}{l}C \\
E\end{array}$ & $\begin{array}{l}141.5 \pm 1.9 \\
140.3 \pm 1.1\end{array}$ & $\begin{array}{l}2.75 \pm 0.10 \\
2.74 \pm 0.12\end{array}$ & $\begin{array}{l}72.7 \pm 1.7 \\
72.6 \pm 2.0\end{array}$ & $\begin{array}{l}1.42 \pm 0.07 \\
1.41 \pm 0.07\end{array}$ \\
\hline $\begin{array}{l}\text { Intact } \\
\text { CTZ } \\
(1 \mathrm{mg} / \mathrm{min})\end{array}$ & $\begin{array}{l}\mathrm{C} \\
\mathrm{E}\end{array}$ & $\begin{array}{l}144.2 \pm 0.9 \\
143.5 \pm 0.9\end{array}$ & $\begin{array}{l}2.86 \pm 0.05 \\
2.89 \pm 0.05\end{array}$ & $\begin{array}{l}73.2 \pm 1.7 \\
71.6 \pm 2.5\end{array}$ & $\begin{array}{l}1.46 \pm 0.12 \\
1.56 \pm 0.16\end{array}$ \\
\hline $\begin{array}{l}\text { Intact } \\
\mathrm{C}^{\prime} T Z \\
(0.75 \mathrm{mg} / \mathrm{min})\end{array}$ & $\begin{array}{l}\mathrm{C} \\
\mathrm{E}\end{array}$ & $\begin{array}{l}142.1 \pm 1.4 \\
145.4 \pm 1.1\end{array}$ & $\begin{array}{l}2.67 \pm 0.07 \\
2.63 \pm 0.05\end{array}$ & $\begin{array}{l}72.6 \pm 1.8 \\
72.4 \pm 1.9\end{array}$ & $\begin{array}{l}1.29 \pm 0.16 \\
1.33 \pm 0.15\end{array}$ \\
\hline $\begin{array}{l}\text { T-P'TX } \\
\text { CTZ } \\
(1 \mathrm{mg} / \mathrm{min})\end{array}$ & $\begin{array}{l}\mathrm{C} \\
\mathrm{E}\end{array}$ & $\begin{array}{l}144.9 \pm 1.2 \\
147.0 \pm 2.4\end{array}$ & $\begin{array}{l}1.96 \pm 0.08 \\
1.96 \pm 0.08\end{array}$ & $\begin{array}{l}59.2 \pm 2.3 \\
59.6 \pm 1.7\end{array}$ & $\begin{array}{l}1.68 \pm 0.17 \\
1.74 \pm 0.17\end{array}$ \\
\hline $\begin{array}{l}\text { T-PTX } \\
\text { CTZ } \\
(1.5 \mathrm{mg} / \mathrm{min})\end{array}$ & $\begin{array}{l}\mathrm{C} \\
\mathrm{E}\end{array}$ & $\begin{array}{l}142.8 \pm 1.1 \\
144.8 \pm 1.1\end{array}$ & $\begin{array}{l}2.18 \pm 0.03 \\
2.15 \pm 0.03\end{array}$ & $\begin{array}{l}61.2 \pm 0.9 \\
61.2 \pm 1.3\end{array}$ & $\begin{array}{l}1.38 \pm 0.15 \\
1.45 \pm 0.15\end{array}$ \\
\hline
\end{tabular}

Abbreviations are as in Table I. Data are given as means \pm SEM. 


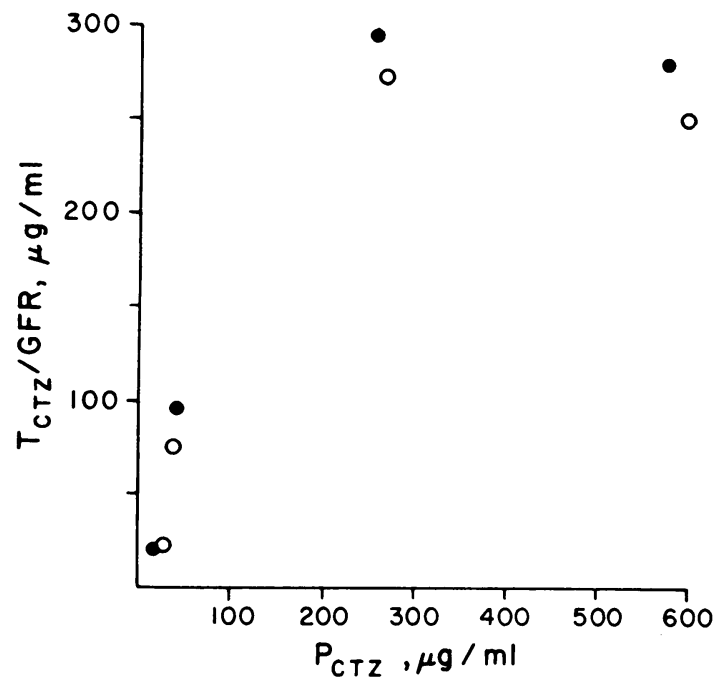

Figure $4 \mathrm{~T}_{\mathrm{CTZ}} / \mathrm{GFR}$ as a function of plasma CTZ concentration in one dog before and after thyro-parathyroidectomy. Closed circles are from an experiment performed before T-PTX; open circles were obtained after surgery. Data are means of two clearance periods at each plasma concentration.

for GFR was $44.2 \mathrm{ml} / \mathrm{min}$; after T-PTX the mean value was $44.4 \mathrm{ml} / \mathrm{min}$. The value for $\mathrm{Tm} / \mathrm{GFR}$ decreased only slightly after T-PTX. These findings were confirmed in the other dogs. The mean value for $\mathrm{Tm} / \mathrm{GFR}$ before T-PTX was $312 \pm 15 \mu \mathrm{g} / \mathrm{ml}$; after surgery the mean was $278 \pm 19 \mu \mathrm{g} / \mathrm{ml}$. The mean value for GFR was $44.2 \pm 2.9 \mathrm{ml} / \mathrm{min}$ before surgery and $48.2 \pm 3.9$ after. The foregoing differences were not statistically significant.

There was, however, a significant difference in the clearance ratios for $\mathrm{CTZ}$ at plasma concentrations well below those necessary for saturation, i.e., less than $50 \mu \mathrm{g}$ / $\mathrm{ml}$. In the intact state, $\mathrm{C}_{\mathrm{crz}} / \mathrm{GFR}$ was $2.38 \pm 0.17$ and after T-PTX, $1.55 \pm 0.20(P<0.05)$. This latter finding is consistent with the observations made during unilateral drug infusion.

Renal extraction of $C T Z$. It seemed possible that the decreased secretion of CTZ in T-PTZ dogs might be attributable to a decreased renal blood flow. Renal blood flow from the left kidney was therefore estimated in 10 normal dogs and 5 dogs $48 \mathrm{~h}$ after thyro-parathyroidectomy. The mean values were $234 \pm 34 \mathrm{ml} / \mathrm{min}$ and $273 \pm$ $46 \mathrm{ml} / \mathrm{min}$, respectively. The difference is not statistically significant. The extraction of $\mathrm{CTZ}$, concentration in arterial plasma - concentration in renal venous plasma /concentration in arterial plasma [(Art-Ven)/Art], was,

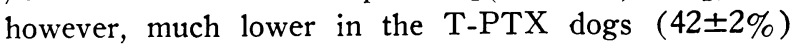
than in the intact dogs $(57 \pm 3 \%), P<0.01$. When either parathyroid extract or parathyroid hormone (PTH) was administered to these same T-PTX dogs, the extraction of $\mathrm{CTZ}$ increased toward normal, $49 \pm$
$3 \%$. The latter value is significantly greater than the pretreatment extraction ratio $(P<0.05)$. Hormone infusion produced a slight increase in renal blood flow above control (from $273 \pm 46$ to $291 \pm 54 \mathrm{ml} / \mathrm{min}$ ), but this was not statistically significant.

\section{DISCUSSION}

The normally linear relationship between fractional excretions of sodium and calcium first described by Walser (28) in dogs has been repeatedly confirmed (32-36). There is no precise agreement on the slope of the line relating the two fractional excretions ( $\mathrm{FE}$ ) ; the equations vary from fractional excretion $\mathrm{FE}_{\mathrm{Ca}}=0.83 \mathrm{FE}_{\mathrm{Na}}+A$ to $\mathrm{FE}_{\mathrm{Ca}}=1.21 \mathrm{FE}_{\mathrm{Na}}+A ; \mathrm{A}$ is the intercept, which is also not exactly the same in all studies. The present results fall within the range described in the literature. The foregoing relationship is known to be disturbed by several interventions, including mineralocorticoid excess or deficiency (37), acidosis (38) parathyroid hormone administration or deficiency (39-42), and the administration of thiazide diuretics, but not most other diuretics (43-47).

The initial administration of a thiazide may result in an increase $(5,7,10)$, a decrease $(3,6)$, or no change $(1,2,9,11-13)$ in fractional calcium excretion. The variable response can, in large part, be explained by the data in Fig. 1. Points $\mathrm{A}$ and $\mathrm{B}$ depict the mean results (left kidneys) from group 2, Table II before and after $\mathrm{CTZ}$, respectively. It is apparent that the change in $\mathrm{C}_{\mathrm{c} a} / \mathrm{GFR}$ can be very nearly predicted from the initial starting point, the slopes of the lines, and the increment in $\mathrm{C}_{\mathrm{Na}} / \mathrm{GFR}$. Points $\mathrm{C}$ and $\mathrm{D}$ are the means of clearance data before and after CTZ from the study of Edwards, Baer, Sutton, and Dirks (14), using saline-expanded dogs. Their results fit reasonably well with this scheme. Note that the increments in $\mathrm{C}_{\mathrm{Na}} / \mathrm{GFR}$ were approximately the same in our experiments ( $A$ and $B$ ) and in those of Edwards et al. ( $C$ and $D$ ). The difference in response of $\mathrm{CCa}_{\mathrm{Ca}} / \mathrm{GFR}$ is attributable to the different starting points on the control line. We also infer from Fig. 1 that differences in the magnitude of natriuretic response to $\mathrm{CTZ}$ from the same starting point will also condition the direction and magnitude of acute changes in $\mathrm{C}_{\mathrm{Ca}} / \mathrm{GFR}$. It seems probable that the failure to observe an absolute fall in calcium excretion in human subjects $(12,13)$ on the first day of thiazide administration is attributable to these factors. These human studies were conducted in a setting of relatively low initial $\mathrm{C}_{\mathrm{Na}} /$ GFR and on the first day of diuretic administration there was a brisk natriuresis.

The present results indicate that volume depletion is not a necessary condition for demonstrating a hypocalciuric response to a thiazide. First, on renal arterial drug infusion there was unilateral fall in calcium clear- 
ance. Volume depletion would be expected to influence both kidneys equally. Second, the hypocalciuric effect was observed in the first clearance period after initiating CTZ infusion (Table I). Over the $15 \mathrm{~min}$ intervening between the start of drug infusion and the end of the first period, the difference between urine flow (both kidneys) and infusion rate totaled only $1.5 \mathrm{ml}$ in the experiment illustrated; i.e., there was no substantial volume depletion. A similar absolute decline in $\mathrm{C}_{\mathrm{ca}}$ had previously been reported by Walser and Trounce in standard clearance experiments in dogs expanded with saline (3). These considerations do not deny a contributory role of volume depletion in the clinical use of thiazides. It seems likely that the diminished natriuretic response to thiazides in volume-depleted subjects would favor an absolute fall in $\mathrm{C}_{\mathrm{C}} / \mathrm{GFR}$ (see above).

The available evidence suggests that neither enhanced secretion of PTH nor the presence of PTH is required for the acute calcium-retaining action of thiazides: $(a)$ It has not been possible to demonstrate an increase in circulating immunoreactive $\mathrm{PTH}$ during thiazide administration (48). (b) Jorgensen demonstrated a hypocalciuric response to bendroflumethiazide in T-PTX rats (11). (c) We could elicit a hypocalciuric response of CTZ in T-PTX dogs (group 5, Table II). (d) There was no increase in c-AMP excretion induced by thiazide administration in our study nor in a study in humans (49). Thus it seems that thiazides mimic the acute renal calcium-conserving action of $\mathrm{PTH}$ by a mechanism that does not require participation of that hormone.

When given into one renal artery, CTZ produced a largely ipsilateral hypocalciuric effect (Table II), indicating that the drug acts directly on the kidney. This evidence for a direct renal action is consistent with a suggestion made by Walser (19). He postulated that thiazides inhibit sodium reabsorption at a distal site where calcium and sodium reabsorption are not coupled and may in fact be negatively correlated.

Brickman, Massry, and Coburn (12), in discussing the possibility that thiazides potentiate the action of $\mathrm{PTH}$ on the nephron, suggested that this potentiation might be the result of thiazides inhibiting phosphodiesterase (50), thereby enhancing the hormone-induced elevated level of c-AMP. A variant of this hypothesis is tenable for the acute effect of thiazides, if one grants the possibility that inhibition of the enzyme per se is sufficient to raise c-AMP levels in the absence of PTH. The failure to find elevated c-AMP excretion after thiazide administration does not eliminate the hypothesis. The action of thiazides on calcium excretion (14), like the actions of PTH on calcium excretion $(39,42,51)$ and antidiuretic hormone $(\mathrm{ADH})$ on urinary osmolality (52), occurs in the distal nephron. With $\mathrm{ADH}$, which presumably acts via a c-AMP mechanism, it has not been possible to demonstrate enhanced excretion of c-AMP (52). Thus, it may well be that elevations of $\mathrm{c}-\mathrm{AMP}$ in distal nephrons are not necessarily accompanied by increased excretion of the nucleotide into urine. It should, however, be emphasized that there is as yet no direct evidence that $\mathrm{PTH}$ enhancement of calcium reabsorption in the distal nephron is mediated by a mechanism involving c-AMP.

In the present study, the probable cause for the defective response to $\mathrm{CTZ}$ in dogs $48 \mathrm{~h}$ after thyro-parathyroidectomy is reduced secretion of the drug. It is known that the natriuretic action of thiazides in dogs (29) and the hypocalciuric action in man (30) are reduced by the administration of probenecid. The latter drug inhibits the secretion of thiazides (53). Such results are consistent with our conclusion that the concentration of thiazide in tubular fluid determines the magnitude of effect. We have not yet been successful in elucidating the nature of the defect in drug secretion caused by thyro-parathyroidectomy. Our experiments rule out the possibility that the $\mathrm{Tm}$ for secretion is seriously diminished or that diminished renal blood flow is responsible for decreased delivery of drug to the kidney. It may be that our T-PTX dogs had an alteration in the transport mechanism, such that its affinity for the drug was diminished when drug concentration was less than that required for saturation. It is also conceivable that the distribution of blood flow in these dogs was such that those nephrons or portions of nephrons secreting CTZ were relatively poorly perfused.

The present results do not seem relevant to the observation that thiazides administered chronically fail to elicit hypocalciuria in hypoparathyroid humans $(12,13)$. It is emphasized that in the experiments with unilateral drug infusion, the remarkable dependence of hypocalciuria on urinary drug excretion was entirely fortuitous. The experimental conditions and the dose of CTZ (1 $\mathrm{mg} / \mathrm{min}$ ) were such that urinary drug concentrations were critical (Fig. 3). It is unlikely that a small difference in CTZ excretion of the magnitude encountered here can explain the defective response of humans with hypoparathyroidism. For example, in a study by Brickman et al. (12), the same absolute dose of hydrochlorothiazide was administered to both normal and hypoparathyroid subjects. However, the body weights in the two groups were different, so that the average dose on a body-weight basis was $30 \%$ higher in the hypoparathyroid group. Theoretically this should have compensated for any defect in drug excretion of the magnitude observed in our dogs. A similar conclusion can be reached from a study by Parfitt (13). Moreover, in a preliminary study, we have not observed defective excretion of $\mathrm{CTZ}$ in humans with chronic stable hypopara-

The Hypocalciuric Action of Chlorothiazide

635 
thyroidism, as compared to normal subjects when the trug was administered intravenously. Such considerations do not rule out other pharmacokinetic bases (e.g. poor intestinal absorption) for the defective response.

\section{ACKNOWLEDGMENTS}

We wish to thank Lieselotte Roth and James P. Tinker for their advice and excellent technical assistance. Margot Szasz and David Gorelick also participated in some of the experiments.

Dr. George M. Fanelli, Jr. of the Merck Institute for Therapeutic Research kindly provided some of the chlorothiazide used for this study.

This study was supported by U. S. Public Health Service grants HE-10595 and 5 TO1 GM 00293.

\section{REFERENCES}

1. Kiil, F. 1960. Permutation trial of diuretics: chlorothiazide and hydroflumethiazide. Circulation. 21: 717723.

2. Poutsiaka, J. W., H. Madissoo, L. G. Millstein, and J. Kirpan. 1961. Effects of benzydroflumethiazide on the renal excretion of calcium and magnesium by dogs. Toxicol. Appl. Pharmacol. 3: 455-458.

3. Walser, M., and J. R. Trounce. 1961. The effect of diuresis and diuretics upon the renal tubular transport of alkaline earth cations. Biochem. Pharmacol. 8: 157. (Abstr.)

4. Higgins, B. A., J. R. Nassim, J. Collins, and A. Hilb. 1964. The effect of bendrofluazide on urine calcium excretion. Clin. Sci. (Oxf.). 27: 457-462.

5. Seitz, H., and Z. F. Jaworski. 1964. Effect of hydrochlorothiazide on serum and urinary calcium and urinary citrate. Can. Med. Assoc. J. 90: 414-420.

6. Duarte, C. G., and J. H. Bland. 1965. Calcium, phosphorus, and uric acid clearances after intravenous administration of chlorothiazide. Metab. (Clin. Exp.). 14: 211-219.

7. Frederick, A., C. Berger, and C. Gharib. 1965. Influénce d'un sulfamide diurétique, l'hydrochlorothiazide, sur l'élimination urinaire du calcium. Therapie. 20: 695-707.

8. Yendt, E. R., R. J. A. Gagné, and M. Cohanim. 1966. The effects of thiazides in idiopathic hypercalciuria. Am. J. Med. Sci. 251: 107-118.

9. Antoniou, L. D., G. M. Eisner, L. M. Slotkoff, and L. S. Lilienfield. 1969. Relationship between sodium and calcium transport in the kidney. J. Lab. Clin. Med. 74: $410-420$

10. Sotorník, I., O. Schück, and J. Strúbrná. 1969. Influence of diuretics on renal calcium excretion. Experientia (Basel). 25: 591-592.

11. J $\phi$ rgensen, F. S. 1971. The effect of bendroflumethiazide (centyl) on the renal excretion of calcium and sodium in normal, parathyroidectomized, thyroidectomized and thyroparathyroidectomized rats. Acta Pharmacol. Toxicol. 30: 296-307.

12. Brickman, A. S., S. G. Massry, and J. W. Coburn. 1972. Changes in serum and urinary calcium during treatment with hydrochlorothiazide: studies on mechanisms. J. Clin. Invest. 51: 945-954.

13. Parfitt, A. M. 1972. The interactions of thiazide diuretics with parathyroid hormone and vitamin D. Studies in patients with hypoparathyroidism. J. Clin. Invest. 51 : 1879-1888.
14. Edwards, B. R., P. G. Baer, R. A. L. Sutton, and J. H. Dirks. 1973. Micropuncture study of diuretic effects on sodium and calcium reabsorption in the dog nephron. J. Clin. Invest. 52: 2418-2427.

15. Lamberg, B. A., and B. Kuhlbäck. 1959. Effect of chlorothiazide and hydrochlorothiazide on the excretion of calcium in urine. Scand. J. Clin. Lab. Invest. 11: 351-357.

16. Suki, W. N., A. R. Hull, F. C. Rector, Jr., and D. W. Seldin. 1967. Mechanism of the effect of thiazide diuretics on calcium and uric acid. J. Clin. Invest. 46: 1121. (Abstr.)

17. Suki, W. N., G. Eknoyan, and M. Martinez-Maldonado. 1972. Control of idiopathic hypercalciuria with diuretics and salt restriction. In Current controversies in urologic management. R. Scott, Jr., editor. W. B. Saunders Company, Philadelphia. 345-350.

18. Pickleman, J. R., F. H. Straus II, M. Forland, and E. Paloyan. 1969. Thiazide-induced parathyroid stimulation. Metab. (Clin. Exp.). 18: 867-873.

19. Walser, M. 1971. Calcium-sodium interdependence in renal transport. In Renal pharmacology. Appleton-Century-Crofts, New York. 21-41.

20. Markowitz, J., J. Archibald, and H. G. Downie. 1964 Experimental surgery. The Williams \& Wilkins Company, Baltimore, Md. 5th ed. 57-89.

21. Lavender, A. R., and T. N. Pullman. 1961. The renal effects of chlorothiazide. J. Pharmacol. Exp. Ther. $134: 281-285$.

22. Wolf, A. V. 1941. Total renal blood flow at any urine flow or extraction fraction. Am. J. Physiol. 133: 496497.

23. Heyrovsky, A. 1956. A new method for the determination of inulin in plasma and urine. Clin. Chim. Acta. $1: 470-474$.

24. Chen, P. S., Jr., T. Y. Toribara, and H. Warmer. 1956. Microdetermination of phosphorus. Anal. Chem. 28: $1756-1758$.

25. Wallach, D. F. H., and T. L. Steck. 1963. Fluorescence techniques in the microdetermination of metals in biological materials. Anal. Chem. 35: 1035-1044.

26. Baer, J. E., H. L. Leidy, A. V. Brooks, and K. H. Beyer. 1959. The physiological disposition of chlorathiazide (Diuril) in the dog. J. Pharmacol. Exp. Ther. 125: 295-302.

27. Toribara, T. Y., A. R. Terepka, and P. A. Dewey. 1957. The ultrafilterable calcium of human serum. I. Ultrafiltration methods and normal values. J. Clin. Invest. 36: 738-748.

28. Walser, M. 1961. Calcium clearance as a function of sodium clearance in the dog. Am. J. Physiol. 200: 1099-1104.

29. Beyer, K. H., and J. E. Baer. 1961. Physiological basis for the action of newer diuretic agents. Pharmacol. Rev. 13: 517-562.

30. Garcia, D. A., and E. R. Yendt. 1970. The effects of probenecid and thiazides and their combination on the urinary excretion of electrolytes and on acid-base equilibrium. Can. Med. Assoc. J. 103: 473-483.

31. Shannon, J. A. 1939. Renal tubular excretion. Physiol. Rev. 19: 63-93.

32. Wesson, L. G., Jr. 1962. Magnesium, calcium and phosphate excretion during osmotic diuresis in the dog. J. Lab. Clin. Med. 60: 422-432.

33. Massry, S. G., J. W. Coburn, L. W. Chapman, and C. R. Kleeman. 1967. Effect of $\mathrm{NaCl}$ infusion on urinary 
$\mathrm{Ca}^{++}$and $\mathrm{Mg}^{++}$during reduction in their filtered loads Am. J. Physiol. 213: 1218-1224.

34. Blythe, W. B., H. J. Gitelman, and L. G. Welt. 1968 Effect of expansion of the extracellular space on the rate of urinary excretion of calcium. Am. J. Physiol. $214: 52-57$

35. Gonda, A., N. Wong, J. F. Seely, and J. Dirks. 1969 The role of hemodynamic factors on urinary calcium and magnesium excretion. Can. J. Physiol. Pharmacol. $47: 619-626$

36. Brickman, A. S., S. G. Massry, and J. W. Coburn. 1969. The effect of calcium deprivation on the calciuretic effect of extracellular volume expansion. Clin. Res. 17 : 425. (Abstr.)

37. Robinson, R. H. B., E. B. Marsh, Jr., J. W. Duckett Jr., and M. Walser. 1962. Adrenocortical modification of the interdependence of calcium and sodium reabsorption in the kidney. J. Clin. Invest. 41: 1394. (Abstr.)

38. Lemann, J., Jr., J. R. Litzow, and E. J. Lennon. 1967. Studies of the mechanism by which chronic metabolic acidosis augments urinary calcium excretion in man. J. Clin. Invest. 46: 1318-1328.

39. Widrow, S. H., and N. G. Levinsky. 1962. The effect of parathyroid extract on renal tubular calcium reabsorption in the dog. J. Clin. Invest. 41: 2151-2159.

40. Massry, S. G., J. W. Coburn, L. W. Chapman, and C. R. Kleeman. 1968. Suppression of parathyroid activity by magnesium infusion. J. Clin. Invest. 47: 66a-67a. (Abstr.)

41. Massry, S. G., J. W. Coburn, L. W. Chapman, and C. R. Kleeman. 1968. Role of serum Ca, parathyroid hormone, and $\mathrm{NaCl}$ infusion on renal $\mathrm{Ca}$ and $\mathrm{Na}$ clearances. Am. J. Phy'siol. 214: 1403-1409.

42. Agus, Z. S., L. B. Gardner, L. H. Beck, and M. Goldberg. 1973. Effects of parathyroid hormone on renal tubular reabsorption of calcium, sodium and phosphate. Am. J. Physiol. 224 : 1143-1148.

43. Kupfer, S., and J. D. Kosovsky. 1965. Effects of cardiac glycosides on renal tubular transport of calcium, magnesium, and inorganic phosphorus and glucose in the dog. J. Clin. Invest. 44 : 1132-1143.
44. Nahmod, V. E., and M. Walser. 1966. The effect oi ouabain on renal tubular reabsorption and cortical concentrations of several cations and on their association with subcellular particles. Mol. Pharmacol. 2: 22-36.

45. Demartini, F. E., A. M. Briscoe, and C. Ragan. 1967. Effect of ethacrynic acid on calcium and magnesium excretion. Proc. Soc. Exp. Biol. Med. 124: 320-324.

46. Duarte, C. G. 1967. Effects of furosemide (F) and ethacrynic acid (ETA) on the renal clearance of phosphate $(\mathrm{CP})$, ultrafilterable calcium $\left(\mathrm{CufC}_{\mathbf{a}}\right)$ and magnesium (CufMg). Clin. Res. 15: 537. (Abstr.)

47. Parfitt, A. M. 1969. The acute effects of mersalyl, chlorothiazide, and mannitol on the renal excretion of calcium and other ions in man. Clin. Sci. (Oxf.). 36: 267282.

48. Stote, R. M., L. H. Smith, D. M. Wilson, W. J. Dube, R. S. Goldsmith, and C. D. Arnaud. 1972. Hydrochlorothiazide effects on serum calcium and immunoreactive parathyroid hormone concentration. Ann. Intern. Med. 77: 587-591.

49. Middler, S., C. Y. C. Pak, F. Murad, and F. C. Bartter. 1973. Thiazide diuretics and calcium metabolism. Metab. (Clin. Exp.). 22: 139-146.

50. Senft, G., K. Munske, G. Schultz, and M. Hoffmann. 1968. Der Einfluss von Hydrochlorothiazid und anderen sulfonamidierten Diuretica auf die 3',5'-AMP-phosphodiesterase-Aktivität in der Rattenniere. Arch. Exp. Pathol. Pharmakol. 259: 344-359.

51. Frick, A., G. Rumrich, K. J. Ullrich, and W. E. Lassiter. 1965. Microperfusion study of calcium transport in the proximal tubules of the rat kidney. Pflïgers Archiv. Gesamte Physiol. Menshen Tiere. 286: 109117.

52. Handler, J. S., and J. Orloff. 1973. The mechanism of action of antidiuretic hormone. Handb. Physiol. Section 8: 791-814.

53. Kessler, R. H., K. Hierholzer, R. S. Gurd, and R. F. Pitts. 1959. Localization of action of chlorothiazide in the nephron of the dog. Am. J. Phy'siol. 196: 13461351. 